\title{
New insights into the distribution and conservation status of the Golden-White Tassel-Ear Marmoset Mico chrysoleucos (Primates, Callitrichidae)
}

\author{
Felipe Ennes Silva ${ }^{1,2}$ (1) - Whaldener Endo ${ }^{3}$. José de Sousa e Silva Júnior ${ }^{4}$ Marcelo A. dos Santos Junior ${ }^{5}$. \\ Ricardo Sampaio ${ }^{3} \cdot$ Fabio Röhe $^{6}$
}

Received: 20 May 2017 / Accepted: 23 April 2018 / Published online: 4 May 2018

(c) The Author(s) 2018

\begin{abstract}
Among the 13 Mico species recognized by the IUCN Red List of Threatened Species, six are listed as "Data Deficient". The geographic range of most of the Mico species has been estimated from only a few records. We report new localities and the geographic extension of Mico chrysoleucos. In addition, we confirmed the presence of the species in two distinct protected areas. We modeled the habitat suitability of $M$. chrysoleucos using the maximum entropy method and including new records obtained by the authors in the state of Amazonas, Brazil. From the total area of occurrence calculated for the species, $22.8 \%$ is covered by protected areas and indigenous lands. The annual mean deforestation rate estimated between 2000 and 2015 was $2.95 \%$, and the total area deforested by 2015 was $3354 \mathrm{~km}^{2}$ or $8.6 \%$ of the total distribution limits of the species. The habitat lost between 2000 and 2015 was $3.2 \%\left(1131 \mathrm{~km}^{2}\right)$ of the total potential distribution, while the habitat loss area legally protected was $31 \mathrm{~km}^{2}$, and the habitat loss in settlements was equal to $691 \mathrm{~km}^{2}$. Our results extend the geographic distribution of the species about $100 \mathrm{~km}$ farther south, with the Maracanã River being a possible geographic barrier for the species. The significantly low rate of habitat loss inside protected areas and indigenous land, when compared to unprotected areas, points out the importance of these areas to $M$. chrysoleucos conservation. The species is relatively wide-ranging, legally protected, and resilient to regional anthropic threats. However, the hydroelectric schemes and the improvement of the road system in southern Amazonia pose an imminent threat to the species.
\end{abstract}

Keywords Amazonian marmosets · Habitat loss · Maximum entropy modeling · Protected areas · Southern Amazonia · Species conservation

Electronic supplementary material The online version of this article (https://doi.org/10.1007/s10329-018-0665-8) contains supplementary material, which is available to authorized users.

Felipe Ennes Silva

interfaceh@gmail.com

1 School of Environment and Life Sciences, University of Salford, Salford M5 4WT, UK

2 Grupo de Pesquisa em Ecologia de Vertebrados Terrestres, Instituto de Desenvolvimento Sustentável Mamirauá (IDSM), Estrada do Bexiga 2584, Fonte Boa, Tefé, Amazonas CEP 69553-225, Brazil

3 National Research Centre for Carnivore Conservation (CENAP), Estrada Municipal Hisaichi Takebayashi 8600, Bairro da Usina, Atibaia, SP, Brazil

\section{Introduction}

The Amazon marmosets of the genus Mico Lesson, 1840, are among the most poorly known Neotropical Primates. Among the 13 species assessed by the IUCN Red List of

4 Museu Paraense Emílio Goeldi, Coordenação de Zoologia, Av. Perimetral, 1909, Belém, PA CEP 66077-530, Brazil

5 Instituto Nacional de Pesquisas da Amazônia (INPA), Coordenação de Pesquisas em Dinâmica Ambiental (CDAM), Instituto Nacional de Ciência e Tecnologia dos Serviços Ambientais da Amazônia (INCT SERVAMB), Manaus, AM, Brazil

6 Instituto de Ciências Biológicas-Depto de Biologia, Wildlife Conservation Society (WCS), Universidade Federal do Amazonas (UFAM), Av. General, Rodrigo Octávio Jordão Ramos 3000-Japiim, Manaus, AM CEP 69077-000, Brazil 
Threatened Species (year published: 2015), six are categorized as Data Deficient. The genus is known to occur in the Madeira-Tocantins interfluve; however, information on the occurrence and distribution of these primates are limited to few records (Ferrari 1993; Silva and Noronha 1995; Noronha et al. 2007; Fialho 2010; Garbino 2011; Silva et al. 2013). The frequent use of secondary growth forest (capoeiras) and the use of other forest types (e.g., Igapó) to explore some specific resources at certain periods of the year have already been reported for the genus Mico (Rylands 1986; Veracini 2009). Comprehensive information on marmoset populations is currently restricted exclusively to $M$. argentatus (Gonçalves et al. 2003) and M. marcai (Silva et al., manuscript accepted, "The Roosevelt-Rondon Expedition Marmoset (Mico marcai): Unveiling a Data-Deficient Species"), underlining the need for a better assessment of the current conservation status of most Mico species.

The golden-white tassel-ear marmoset Mico chrysoleucos (Wagner, 1842) was categorized as Vulnerable in 1994 in the IUCN Red List, but its category changed to Data Deficient in 2003 because of the lack of information on the limits of its distribution range, population status, and threats (Rylands and Silva-Júnior 2015). The species occurs in the Brazilian state of Amazonas, east of the lower Madeira River (Hershkovitz 1977; Rylands et al. 2009). Until recently, there were no protected areas (hereafter, PAs) encompassing the known geographic range of the species, raising additional concerns about the species' conservation status.

The Madeira River has been identified as one of the top conservation priority areas of the Amazon Biome (Mesquita et al. 2007; Rapp Py-Daniel 2007). The high mammal diversity found in recent inventories, and the scarcity of published studies on the region's biodiversity, highlight the need for a more comprehensive assessment of the taxonomy, ecology, biogeography, distribution, and abundance of the fauna occurring in this area. For example, Röhe (2007) recorded 20 primate species in three interfluves in the Madeira River basin: PurusMadeira, Madeira-Aripuanã e Aripuanã-Acari.

Here we report a multiyear survey of $M$. chrysoleucos in the southern part of the Brazilian Amazon, in order to better understand the extent of the species' geographical range and its current conservation status, more specifically, its occurrence inside the existing PAs. We modeled the M. chrysoleucos distribution to estimate the area of occurrence and the habitat loss in that region. Based on this dataset, we contributed to the assessment of its conservation status according to the criteria of the IUCN Red List.

\section{Methods}

The study area, estimated at $3919 \mathrm{~km}^{2}$, is located in the middle Madeira River, central Amazonia, Brazil. The climate is tropical, with a short dry season, mean annual temperature of $28{ }^{\circ} \mathrm{C}$, and mean annual precipitation of 2500 to $3000 \mathrm{~mm} /$ year (Hayakawa and Rossetti 2015). The vegetation is mostly comprised of upland unflooded forest (terra firme), seasonally flooded forests (várzea), and by patches of campinaranas - a dense low canopy forest grown over weathered sandy soils and dominated by palms, shrubs, and lichens (Anderson 1981).

\section{Primate survey}

We used rapid survey methods for mammal inventories (Fonseca 2001; Young et al. 2003) totaling 44 days of a multiyear survey. Surveys were conducted on land using existing trails and roads, and on board of small boats along the rivers' edges searching for the species presence (National Research Council 1981).

Two surveys were conducted during the dry season (September 2004, 2010) and three were done during the wet season (March 2007 and January 2012, 2013). In September 2004, FR conducted surveys in the newly created Juma Sustainable Development Reserve as part of a faunal survey in the middle Madeira River (Röhe 2007). During 9 days, the region between the Aripuanã and Acari Rivers was surveyed. In March 2007, a 15-day survey was carried out by WE in the Aripuanã Sustainable Development Reserve. Several brief surveys in the flooded and unflooded forest were conducted on both banks of the Aripuanã River, but with a higher survey effort allocated to the right bank. In September 2010, on the lower course of the Madeira River, near the city of Autazes and close to its confluence with the Amazonas River, RS carried out a 10-day mammal survey along both sides of the river. The sites included flooded and unflooded forests. During January 2012 and 2013, FES carried out a primate survey on the middle course of the Aripuanã River, close to the confluence of the Roosevelt and Aripuanã Rivers, surveying in both banks and using a playback of Mico sp. long call to locate the marmosets.

\section{Species distribution modeling}

We georeferenced all sightings using Global Position System (GPS) devices. The presence records obtained in the field were posteriorly complemented with data found in the literature (Hershkovitz 1977; Silva and Noronha 1995). We estimated the species habitat suitability using the maximum entropy algorithm with MaxEnt (Phillips et al. 2004, 
2006) and its potential distribution using the lowest presence threshold approach (LPT) choosing the lowest predicted value associated with any one of the observed presence records across the landscape (Pearson et al. 2007).

In other words, in all pixels above LPT value, the species was considered as being present. We select the model input points removing duplicate presence records in the same pixel using at final 21 occurrence points in the modeling process, the minimum distance between the remaining occurrence points is $1.6 \mathrm{~km}$. We choose the model with lower overfitting based on AUC difference between Training AUC and Test AUC (see also supplemental material).

We calculated the deforestation rate for the distribution limits proposed here using deforested areas identified by PRODES-Satellite Monitoring Project of the Brazilian Amazon Rainforest (PRODES 2014) from 2000 to 2015. To estimate the habitat loss, we removed the deforested areas from 2000 to 2015 from the potential distribution map and calculated the habitat loss rate in this period. We constructed the models using R software (R Core Team 2015) with the dismo package (Hijmans et al. 2016).

We also calculated total habitat loss to date within our newly calculated $M$. chrysoleucos' range and used previous predictive deforestation models (Soares-Filho et al. 2006) to assess how much of the species range will be lost by 2036 (in 18 years). This period represents the three-generation time estimated for Mico (Mittermeier and Rylands 2008; Nishijima et al. 2012), according to the IUCN criteria for the first level of a threat category, Vulnerable (VU) (IUCN 2012). For the predicted forest loss construction of our predictive models of habitat loss, we considered two scenarios (after Soares-Filho et al. 2006):

1. "Governance" scenario, i.e., assuming (1) current deforestation trends, but with a 50\% cap in forest loss due to current laws that prohibit farmers to clear more than $50 \%$ of forest in their properties, and (2) that existing and proposed protected areas are effectively managed.

2. "Business-as-usual" scenario, i.e., considering current deforestation trends across the Amazon basin plus the effect of infrastructure development and low management effectiveness of protected areas.

\section{Results}

We obtained 14 records of M. chrysoleucos (Fig. 1, Fig. S1, Table S1). The species occurs on the north bank of the Paraná do Urariá, but the northern limit is not well known, and probably extends to Paraná Ramos-a small channel on the right bank of Amazon River. Our records on the Maracanã River extends the species distribution $100 \mathrm{~km}$ farther south (Fig. S1).
In the Aripuanã Reserve, individuals were observed at the interface of unflooded and flooded forests. At Juma Sustainable Development Reserve and at the Roosevelt-Aripuanã confluence, the species was detected exclusively in secondary forests. Mico responded promptly to playback recordings on two occasions. We recorded the species at the same places were troops of white-nosed bearded sakis (Chiropotes albinasus) and tufted capuchins (Sapajus apella) were foraging on two distinct occasions.

The annual deforestation rate between 2000 and 2015 was $2.95 \%$. The accumulated deforestation area up to 2015 within the species range proposed was $3354 \mathrm{~km}^{2}$, corresponding to $8.6 \%$ from the area of geographic distribution limits.

The model that we fitted with the parameters selected using ENMeval package (Muscarella et al. 2014) provided a good predictability (mean AUC DIFF $=0.153$ and the $\mathrm{AIC}=568.92$, Fig. S3). The LPT value found was $35.3 \%$. The species potential distribution covers $37,151 \mathrm{~km}^{2}$ corresponding to $95 \%$ of the species range proposed without deforestation. Considering the deforestation by 2000, this area is equal to $94 \%$ and changed to $91 \%$ in 2015 . PAs and Indigenous Lands (hereafter, ILs) covered $22.7 \%$ of the area predicted for the species distribution (Table 1). Finally, according to the distribution model, we expect the species occurrence to include four other PAs and two ILs (Fig. 1), totaling an area of $7798 \mathrm{~km}^{2}$ inside areas legally protected. The habitat loss of 2000 to 2015 was 3.2\% of the total potential distribution $\left(1131 \mathrm{~km}^{2}\right)$. The habitat loss area legally protected was $31 \mathrm{~km}^{2}$ (Table 1), and in settlements was equal to $691 \mathrm{~km}^{2}$. In our analysis considering the predictive deforestation models by Soares-Filho et al. (2006), the species' future habitat loss in the next 18 years will amount to $14,254 \mathrm{~km}^{2}(38.3 \%)$ under the Governance scenario, and to $20,337 \mathrm{~km}^{2}(54.6 \%)$ under the Business as Usual scenario.

\section{Discussion}

The extension of the geographic range of $M$. chrysoleucos farther south, the first confirmation of the species occurrence inside two distinct PAs, and the potential inclusion of the species occurrence in four other PAs and two more ILs have important implications for the assessment of its conservation status. A basic measure of the effectiveness of a PA is how well its forest cover has been preserved (Barber et al. 2012). Based on this assumption, the low percentage of habitat loss occurring inside the PAs and ILs suggests that these areas are properly safeguarding the $M$. chrysoleucos populations occurring within their borders (Table 1).

Our records of $M$. chrysoleucos at the interface of flooded and unflooded forests suggest a tolerance for the seasonal disruption of certain food supplies. However, 
Fig. 1 Habitat suitability, deforested lands, and protected areas for Mico chrysoleucos

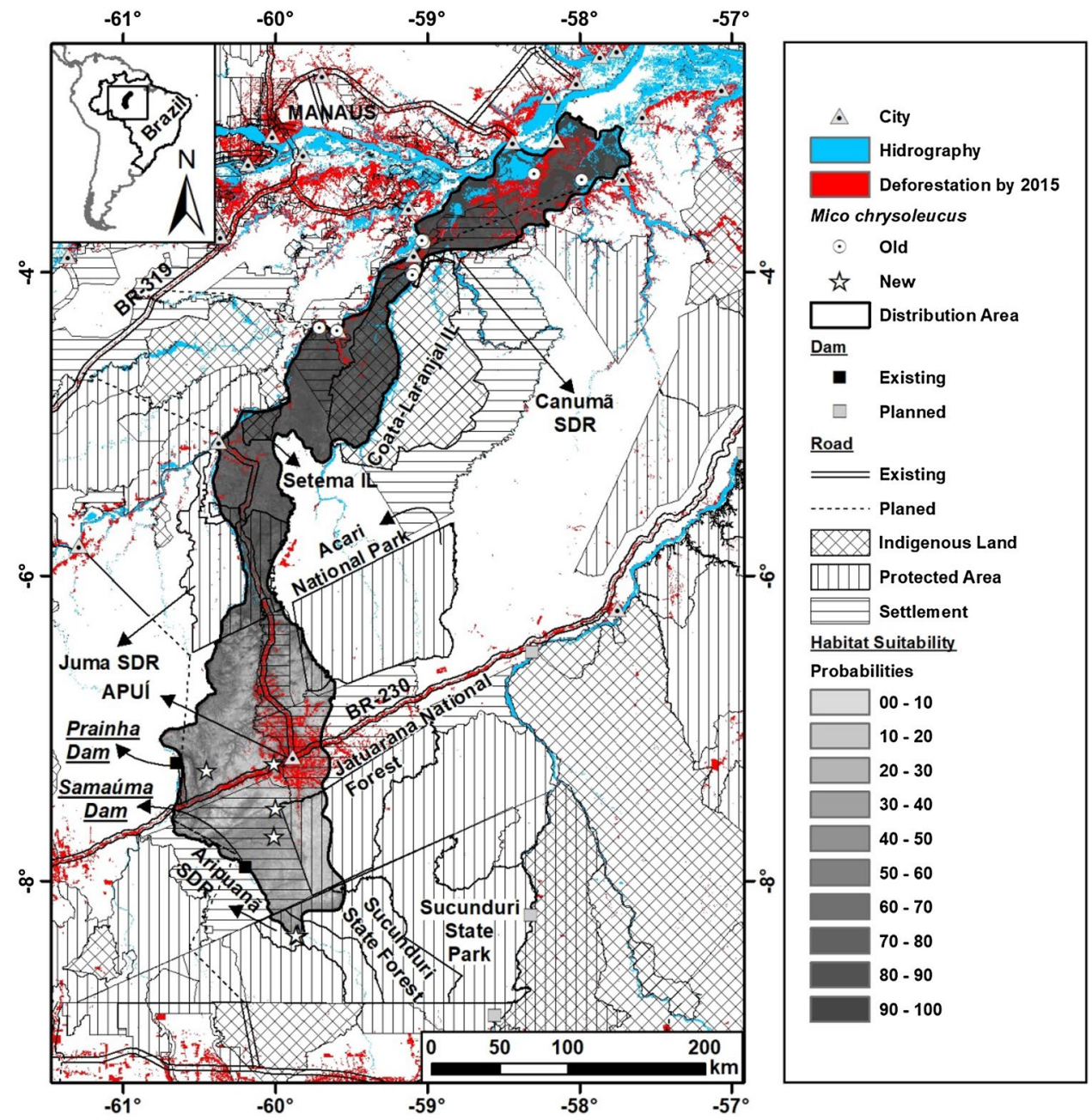

Table 1 Area predicted considering deforestation by 2015 and the habitat lost between 2000 and 2015 for M. chrysoleucos

\begin{tabular}{llll}
\hline Parameter & \multicolumn{2}{l}{ Area $\mathrm{km}^{2}(\%)$} \\
\cline { 2 - 3 } & \multicolumn{2}{l}{ Predicted with deforestation } & Lost \\
\cline { 2 - 3 } & 2000 & 2015 & \\
\hline Total area & $34,949(100.0)$ & $33,818(96.8)$ & $1131(3.2)$ \\
Protected areas & $3898(11.2)$ & $3871(10.5)$ & $28(0.7)$ \\
Indigenous lands & $3930(11.2)$ & $3927(11.1)$ & $3(0.1)$ \\
Settlement & $9507(29.9)$ & $8833(23.3)$ & $691(6.6)$ \\
Nonprotected & $17,614(47.7)$ & $17,187(45.3)$ & $409(2.4)$ \\
\hline
\end{tabular}

members of the Callithrichinae family are not considered to be adapted to large tracts of flooded forest that are far removed from terra firme forests and subjected to an annual flood pulse (Haugaasen and Peres 2009). The records of $M$. chrysoleucos in secondary forests suggest a similarity of its ecology with other Amazonian marmosets, frequently found in this type of habitat (Rylands 1986; Ferrari 1992; Veracini 2009).
The apparent resilience of the species to anthropogenic habitat disturbance and the lack of major threats identified for M. chrysoleucos were the arguments used to support the species categorization as "Least Concern" in the Brazilian workshop for the Assessment of the Extinction Risk of Brazilian Primates. Our data partially support this category if we consider the following key factors: broad distribution (>20,000 km², against the criteria B1 for "Vulnerable"); more than $20 \%$ of the area predicted for the species distribution legally protected and with low rates of deforestation; and the accumulated deforestation up to 2015 below the $10 \%$ of the area predicted for the species occurrence. However, under a 'Business as Usual' scenario, our predictive model projected a total loss of $54.6 \%$ of the species total range by 2036, in accordance with the criterion A3c for Vulnerable (IUCN 2012), shedding light on its long-term conservation. The hydroelectric schemes and the improvement of the road system are two imminent threats that represent a high degree of uncertainty to this marmoset, therefore recommending caution to place M. chrysoleucos as "Least Concern". For example, two reservoirs planned in the Aripuanã River will 
flood an area of $682.30 \mathrm{~km}^{2}$ (ANEEL 2012) and will affect PAs and ILs (Silva et al. 2013), the key factor for protection against habitat loss.

The implementation of hydroelectric schemes is closely related to the road network expansion, as reported for Balbina Dam and the BR-174 highway (Fearnside 1989, 2015). This association is a powerful driver of land use and cover change, resulting in large deforested areas and in habitat loss for forest species (Laurance et al. 2002; Soares-Filho et al. 2004, 2005; Fearnside 2005; Fearnside et al. 2009; Fearnside 2007; Fearnside et al. 2009; Graça et al. 2014; Barni et al. 2015; Santos Junior et al. 2015). Indeed, 94.9\% of all deforestation in the Brazilian Amazon has occurred in a well-defined accessible zone within $5.5 \mathrm{~km}$ of some type of roadway (Barber et al. 2014). In this scenario, the PAs are essential in mitigating the deforestation risk, as shown elsewhere (Barber et al. 2012, 2014).

The Brazilian System of PAs includes two broad categories of protection (Rylands and Brandon 2005; Walker et al. 2009): Strictly PAs and PAs with Sustainable Use of Natural Resources. The first category primarily aims to conserve biodiversity and is not open to renewable natural resource extraction. The latter category aims to conciliate maintainable levels of land use and natural resource extraction with biodiversity conservation. ILs in Brazil are under the jurisdiction of the Brazilian Indian Foundation (Fundação Nacional do Índio), but they are not assigned to an IUCN PA category. The two PAs where we recorded M. chrysoleucos were created recently: Aripuanã Sustainable Development Reserve and Juma Sustainable Development Reserve. The first was created in 2005 and is one of the eight contiguous PAs forming a single 2,600,000-ha triangular area known as the Apuí Mosaic. The area was originally proposed to block the expansion of deforestation on the southern edge of the Brazilian Amazon forest, which suffers from a dramatic rate of habitat destruction (Nepstad et al. 2001; Fearnside 2005). The Aripuanã Reserve is also known to fall within the range of Mico intermedius and, possibly, Mico melanurus, indicating the importance of this area for the conservation of Amazonian marmosets. The second, Juma Reserve, was created in 2006 and represents the greatest portion of the species distribution already encompassed by the existing PAs. Recent surveys confirm the presence of two other marmosets inside this reserve: Mico marcai and Callibella humilis (Röhe 2007). This 590,000-ha area of PA was created to restrain the advance of deforestation along the road AM-174, which connects the Apuí and Novo Aripuanã cities throughout the $M$. chrysoleucos distribution.

Areas composed of reserves with multiple levels of use restriction are expected to better conserve source areas while allowing local rural populations to remain in the local and to exploit the natural resources found locally. The set of PAs known as the "Apuí Mosaic" consists of areas with different management purposes: strictly PAs (such as National Parks), and PAs that conserve ecosystems associated with cultural values and traditional natural resource management systems. Following this strategy, we expect the set of PAs in the south of Amazon State to preserve a great number of distinct forest types and thereby to assist in the conservation of Amazon marmosets occurring within this range. In addition, to understand how the infrastructure projects affect the conservation status of $M$. chrysoleucos, the next step for a broad assessment is the data collection of population parameters. There are no population data to include in its conservation assessment following the IUCN criteria (Rodrigues et al. 2006; Mace et al. 2008). The assessment of M. chrysoleucos should be reviewed carefully given the expected rate of change in the landscape in the next few years.

Acknowledgements The study was part of a biological survey financed by Secretaria de Estado do Meio Ambiente e Desenvolvimento Sustentável do Amazonas (SDS) to serve as baseline information to help the establishment of new PAs in the Amazonas State. FES was supported by Mamirauá Institute for Sustainable Development, Conservation Leadership Programme (CLP), Conselho Nacional de Desenvolvimento Científico e Tecnológico (CNPq 200502/2015-8), Idea Wild, International Primatological Society, Conservation International, Primate Conservation Inc., and International Association for Conscientiology Expansion. RS was supported by FAPEAM (Process number: 606/10). The authors also thank CLP Workshop "Writing for Conservation" and to Dr. Martin Fisher for the important comments on the manuscript.

Open Access This article is distributed under the terms of the Creative Commons Attribution 4.0 International License (http://creativeco mmons.org/licenses/by/4.0/), which permits unrestricted use, distribution, and reproduction in any medium, provided you give appropriate credit to the original author(s) and the source, provide a link to the Creative Commons license, and indicate if changes were made.

\section{References}

Anderson AB (1981) White-Sand Vegetation of Brazilian Amazonia. Biotropica 13:199-210

ANEEL (2012) DESPACHO Nº 1.971, DE 12 DE JUNHO DE 2012. http://www.aneel.gov.br/biblioteca/inventario.cfm. Accessed 13 Jul 2015

Barber CP, Cochrane MA, Souza C, Veríssimo A (2012) Dynamic performance assessment of protected areas. Biol Conserv 149:6-14

Barber CP, Cochrane MA, Souza CM Jr, Laurance WF (2014) Roads, deforestation, and the mitigating effect of protected areas in the Amazon. Biol Conserv 177:203-209

Barni PE, Fearnside PM, Graça PMLA (2015) Simulating deforestation and carbon loss in Amazonia: impacts in Brazil's Roraima state from reconstructing Highway BR-319 (Manaus-Porto Velho). Environ Manage 55(2):259-278

Fearnside PM (1989) Brazil's Balbina Dam: environment versus the legacy of the pharaohs in Amazonia. Environ Manage 13(4):401-423

Fearnside PM (2005) Brazil's Samuel Dam: lessons for hydroelectric development policy and the environment in Amazonia. Environ Manage 35:1-19 
Fearnside PM (2007) Brazil's Cuiabá-Santarém (BR-163) Highway: the environmental cost of paving a soybean corridor through the Amazon. Environ Manage 39(5):601-614

Fearnside PM (2015) Hidreletricas na Amazônia: impactos ambientais e sociais na tomada de decisões 0sobre grandes obras / Philip M. Fearnside. Editora do INPA, Manaus, v. 1. ISBN: 978-85-211-0143-7

Fearnside PM, Graça PMLA, Keizer EWH, Maldonado FD, Barbosa RI, Nogueira EM (2009) Modelagem de desmatamento e emissões de gases de efeito estufa na região sob influência da rodovia Manaus-Porto Velho (BR-319). Revista Brasileira de Meteorologia 24(2):208-233

Ferrari SF (1992) Update of Callithrix nigriceps distribution.pdf. Neotrop Primates 1:11-13

Ferrari S (1993) Update of Callithrix nigriceps distribution.pdf. Neotrop Primates 1:11-13

Fialho MDS (2010) Contribuição à distribuição do gênero Mico, (Callitrichidae, Primates) no médio Teles Pires, Jacareacanga, Pará. Neotrop Primates 17:21-22

Fonseca GAB (2001) Proposta para um programa de avaliação rápida em âmbito nacional. In: Garay I, Dias B (eds) Conservação da Biodiversidade em Ecossistemas Tropicais. Editora Vozes, Petrópolis, pp $150-156$

Garbino GST (2011) The southernmost record of Mico emiliae (Thomas, 1920) for the state of Mato Grosso, northern Brazil. Neotrop Primates 18:53-55

Gonçalves EC, Ferrari SF, Silva AL, Coutinho PEG, Menezes EV, Schneider MP (2003) Effects of habitat fragmentation on the genetic variability of silvery marmosets, Mico argentatus. In: Marsh LK (ed) Primates in fragments: ecology and conservation. Kluwer Academic Publishers, New York, pp 17-28

Haugaasen T, Peres CA (2009) Interspecific primate associations in Amazonian flooded and unflooded forests. Primates 50:239-251

Hayakawa EH, Rossetti DF (2015) Late quaternary dynamics in the Madeira River basin, southern Amazonia (Brazil), as revealed by paleomorphological analysis. An Acad Bras Cienc 87:29-49

Hershkovitz P (1977) Living New World monkeys (Platyrrhini) with an introduction to primates, vol 1. University of Chicago Press, Chicago

Hijmans RJ, Phillips S, Leathwick J, Elith J (2016) dismo: species distribution modeling. $\mathrm{R}$ package \#version 1.0-15

IUCN (2012) IUCN Red List Categories and Criteria, vol 2. IUCN, Gland

Laurance WF, Albernaz AKM, Schroth G, Fearnside PM, Bergen S, Venticinque EM, da Costa C (2002) Predictors of deforestation in the Brazilian Amazon. J Biogeogr 29:737-748

Mace GM, Collar NJ, Gaston KJ, Hilton-Taylor C, Akakaya HR, Leader-Williams N, Milner-Gulland EJ, Stuart SN (2008) Quantification of extinction risk: IUCN's system for classifying threatened species. Conserv Biol 22:1424-1442

Mesquita R, Marinelli CE, Pinheiro PS (2007) Ciência e formulação de políticas de conservação na amazônia. In: Rapp Py-Daniel L, Deus CP, Henriques AL et al (eds) Biodiversidade do Médio Madeira: Bases científicas para propostas de conservação. INPA, Manaus, pp 239-244

Mittermeier RA, Rylands AB (2008) Mico leucippe. The IUCN red list of threatened species. http://doi.org/10.2305/IUCN.UK.2008. RLTS.T39912A10283351.en. Accessed 20 Nov 2017

Muscarella R, Galante PJ, Soley-Guardia M, Boria RA, Kass JM, Uriarte M, Anderson RP (2014) ENMeval: an R package for conducting spatially independent evaluations and estimating optimal model complexity for maxent ecological niche models. Methods Ecol Evol 5:1198-1205

Nepstad D, Carvalho G, Cristina Barros A, Alencar A, Paulo Capobianco J, Bishop J, Moutinho P, Lefebvre P, Lopes Silva U, Prins
E (2001) Road paving, fire regime feedbacks, and the future of Amazon forests. For Ecol Manag 154:395-407

Nishijima K, Saitoh R, Tanaka S, Ohsato-Suzuki M, Ohno T, Kitajima $S$ (2012) Life span of common marmoset (Callithrix jacchus) at CLEA Japan breeding colony. Biogerontology 13:439-443

Noronha MA, Spironello WR, Ferreira DC (2007) New occurrence records of Mico acariensis (Primates, Callitrichidae). Neotrop Primates 14:140

Pearson RG, Raxworthy CJ, Nakamura M, Peterson AT (2007) Predicting species distributions from small numbers of occurrence records: a test case using cryptic geckos in Madagascar. J Biogeogr 34(1):102-107

PRODES (2014) Projeto Prodes. http://www.dpi.inpe.br/prodesdigital/ prodes.php. Accessed 14 Jul 2014

Phillips SJ, Dudík M, Schapire RE (2004) A maximum entropy approach to species distribution modeling. In: Proceedings of the 21st international conference on machine learning, Banff, Canada

Phillips SJ, Anderson RP, Schapire RE (2006) Maximum entropy modeling of species geographic distributions. Ecol Modell 190:231-259

R Core Team (2015) R: a language and environment for statistical computing. R Foundation for Statistical Computing, Vienna, Austria

Rapp Py-Daniel L (2007) Biodiversidade Do Médio Madeira - Contextualização do projeto e financiamento. In: Rapp Py-Daniel L, Deus $\mathrm{CP}$, Henriques AL et al (eds) Biodiversidade do Médio Madeira: Bases científicas para propostas de conservação. INPA, Manaus, pp 19-23

Rodrigues ASL, Pilgrim JD, Lamoreux JF, Hoffmann M, Brooks TM (2006) The value of the IUCN Red List for conservation. Trends Ecol Evol 21:71-76

Röhe F (2007) Mamíferos de médio e grande porte. In: Rapp PyDaniel L, Deus CP, Henriques AL et al (eds) Biodiversidade do Médio Madeira: Bases científicas para propostas de conservação. INPA, Manaus, pp 195-209

Rylands AB (1986) Ranging behaviour and habitat preference of a wild marmoset group, Callithrix humeralifer (Callitrichidae, Primates). J Zool 10:489-514

Rylands AB, Brandon K (2005) Brazilian Protected Areas.pdf. Conserv Biol 19:612-618

Rylands AB, Silva-Júnior J de S (2015) Mico chrysoleucos. The IUCN Red List of Threatened Species. Version 2015.2. www.iucnredlis t.org. Accessed 13 Jul 2015

Rylands AB, Coimbra-Filho AF, Mittermeier RA (2009) Systematic and Distributions of the Marmosets (Callithrix, Callibella, Cebuella, and Mico) and Callimico (Callimico) (Callithrichidae, Primates). In: Ford SM, Porter ML, Davis L (eds) The smallest anthropoids: the marmoset/callimico radiation. Springer, New York, pp 25-61

Santos Junior MA dos, Graça PML de A, Rocha VM, Silva RTM da, Bobrowiec PED, Tavares V da C, Fearnside PM (2015). Cenários de desmatamento e avaliação preditiva de perda de habitat na região de influência da rodovia BR-319. In: Anais XVII Simpósio Brasileiro de Sensoriamento Remoto-SBSR. Instituto Nacional de Pesquisas Espaciais (INPE), João Pessoa, pp 5694-5701

Silva JS Jr, Noronha MA (1995) A new record for Callithrix mauesi Mittermeier, Schwarz and Ayres, 1992. Neotrop Primates 3:79-81

Silva FE, Nunes HG, Bastos A (2013) Rediscovery of Marca's marmoset and the challenges for its conservation. Oryx 47:13

Soares-Filho BS, Alencar A, Nepstad DC, Cerqueira G, del Diaz M CV, Rivero S, Solórzano L, Voll E (2004) Simulating the response of land-cover changes to road paving and governance along a major Amazon highway: the Santarém-Cuiabá corridor. Glob Change Biol 10:745-764

Soares-Filho BS, Nepstad DC, Curran L, Cerqueira GC, Garcia RA, Ramos CA, McDonald A, Lefebvre P, Schlesinger P, McGrath 
D (2005) Cenários de desmatamento para a Amazônia. Estudos Avançados 19(54):138-152

Soares-Filho BS, Nepstad DC, Curran LM, Cerqueira GC, Garcia RA, Ramos CA, Voll E, McDonald A, Lefebvre P, Schlesinger $P$ (2006) Modelling conservation in the Amazon basin. Nature 440:520-523

Veracini C (2009) Habitat use and ranging behavior of the silvery marmoset (Mico argentatus) at Caxiuanã National Forest (eastern Brazilian Amazonia). In: Ford SM, Porter ML, Davis LC (eds) The smallest anthropoids: the marmoset/callimico radiation. Springer, New York, pp 221-240

Walker R, Moore NJ, Arima E, Perz S, Simmons C, Caldas M, Vergara D, Bohrer C (2009) Protecting the Amazon with protected areas. Proc Natl Acad Sci USA 106:10582-10586

Young B, Sedaghtkish G, Rocha R (2003) Levantamentos de fauna. In: Sayre R, Roca E, Sedagahtkish G, Young B, Roca R, Sheppard S (eds) Natureza em foco: avaliação ecológica rápida. The Nature Conservancy, Arlington 